\title{
The Delaney Clause: Technical Naïveté and Scientific Advocacy in The Formulation of Public Health Policies
}

\author{
Charles H. Blank*
}

\section{INTRODUCTION}

On April 26, 1973, newspaper stories ${ }^{1}$ announced that the Food and Drug Administration (FDA) had banned further use of diethylstilbestrol (DES) in fattening cattle. In another time this detail of federal food technology regulation might have languished unheralded in the Federal Register, but on that Thursday the press not only reported the new rule but gave it front-page treatment.

What made the regulation so newsworthy was its enactment only a few weeks after a national boycott called to protest the high cost of meat. $^{2}$ In pronulgating the new regulation the government was deliberately taking action which was certain to cause the price of beef to increase, perhaps as much as 15 cents per pound. ${ }^{3}$ Because DES shortens the time and reduces the ainount of feed required to raise an animal for market, ${ }^{4}$ the ban was certain to raise the cost of beef production. In 1972 the FDA had prohibited the use of DES in animal feed, but continued to permit administration of the agent to cattle by nieans of ear implants. ${ }^{5}$ The new regulation ${ }^{0}$ finally ended use of

* Ph.D. (genetics) 1968, J.D. 1974, University of California, Berkeley. United States Public Health Service Postdoctoral Fellow, School of Medicine, University of California, San Diego (1970-71).

1. E.g., N.Y. Times, Apr. 26, 1973, at 1, col. 5.

2. E.g., NewsweEk, Apr. 2, 1973, at 19.

3. N.Y. Times, Apr. 26, 1973, at 15, col. 1 [hereinafter cited as N.Y. Times].

4. As FDA Commissioner Edwards testified:

DES promotes morc rapid weight gain with concomitant shorter feeding time and reduced quantities of feed. For example, a 500-pound animal will reach a marketable weight of 1,050 pounds using 511 pounds less feed and 31 days sooner when fed DES-containing feed.

Statement of FDA Commissioner Charles Edwards, M.D., Regulation of Diethylstilbestrol, Hearings on H.R. 8708 Before a Subcomm. of the Comm. on Gov't Operations, 92d Cong., 1st Sess., pt. 1, at 53 (1971) [hereinafter cited as DES Hearings].

5. The FDA prohibited further manufacture of DES-fortified feed on Aug. 4, 1972, but it allowed pre-existing feed containing DES to be used until Jan. 1, 1973. 37 Fed. Reg. 15747, 26307 (1972); DES Hearings, supra note 4, pt. 3, at 353-59. Use 
DES altogether. Other growth stimulants are available but are less useful because of greater cost or inferior efficacy. ${ }^{7}$

In banning DES, the FDA was acting in compliance with the policy enunciated by the Delaney clause of the Food, Drug and Cosmetic Act (FDCA). ${ }^{8}$ The ban is only the most recent episode in a series of events which has placed the Delaney clause at the center of an ongoing, heated, and expanding controversy. ${ }^{9}$

Directed toward the objective of consumer health protection, the clause provides, essentially, that no additive is to be tolerated in food (in any amount however slight) if the substance in question (at any dose however great) causes cancer in man or animals. ${ }^{10}$ The scope of the law is even broader than is apparent from this description. This is so because the term "food additive" refers not only to a substance deliberately added to food during processing so as to becoine an intentional component, but also to any substance used in such a way that it could reasonably be expected to becoine an inadvertent component. ${ }^{11}$

The prime source of dissatisfaction with the Delaney clause is that it prohibits the FDA from following the practice it normally follows with respect to noxious substances other than carcinogens. For other kinds of substances, the FDA has discretion to set upper limits of contamination or adulteration, based on such considerations as the rela-

of DES implants was permitted pending the results of tests conducted by the U.S. Department of Agriculture (USDA). Id. at 359.

6. 38 Fed. Reg. 10485, 10926 (1973).

7. N.Y. Times, supra note 3. Actually, DES came back into use, although probably only temporarily, at the beginning of 1974. In January, the D.C. Circuit vacated the orders which withdrew approval of use of DES in cattle feed and ear implants, holding that the FDA erred in failing to grant the pre-withdrawal hearings sought by DES manufacturers. Hess \& Clark, Div. of Rhodia, Inc. v. Food \& Drug Admin., 495 F.2d 975 (D.C. Cir. 1974); Chemetron Corp. v. United States Dep't of HEW, 495 F.2d 995 (D.C. Cir. 1974). The FDA responded by giving notice that it proposed to revoke approval of all methods for identifying DES residues in edible tissue. 39 Fed. Reg. 11299 (1974). It announced that following disposition of this proposal, it would give notice of opportunity for hearing on another plan to withdraw approval of use of DES in cattle feed and ear implants. Id.

8. As is discussed in Section I infra, the FDA in banning DES acted not under the Delaney clause itself, 21 U.S.C. \& 348(c)(3)(A) (1970), but under section 360 (b)(d)(1)(H). 37 Fed. Reg. 15749 (1972); 39 Fed. Reg. 11299 (1974). This distinction is not important, however, because the provisions of the latter section were specifically drafted to apply the policy and language of the clause to regulation of certain practices, including administration of DES to cattle by means of ear implants. Id.

9. See Wade, Delaney Anti-Cancer Clause: Scientists Debate on Article of Faith, 177 Scrence 588-91 (1972) [hereinafter cited as Debate]; Culliton, Delaney Clause: Defended Against an Uncertain Threat of Change, 179 SCIENCE 666-67 (1973) [hereinafter cited as Uncertain Threat].

10. See text accompanying notes 39-42 infra.

11. See text accompanying notes $39-40$ infra. 
tive toxicity of each particular substance and its utility in producing or processing the particular food in which it appears. ${ }^{12}$

The case for the clause is simply stated. Its advocates maintain that the effects of carcinogens are insidious, irreversible, and cumulative. ${ }^{13}$ Cancer is an increasingly common disease which is a personal catastrophe and a great social burden. ${ }^{14}$ Because there is no reliable method to deinonstrate that any amount of a given carcinogen is safe, they argue, the limits of the threshold of harm are at present indeterminate. Since no level, however conservative, is known to be safe, carcinogens should be banned from all foods for liuman consumption. ${ }^{15}$

The clause, dating froin 1958, lias caused imcreasing difficulty with the passage of time. The accumulation of new knowledge las resulted in substances once regarded as harmless coming to be recognized as at least potentially carcinogenic. For example, it was belatedly discovered in 1969 that the artificial sweetener cyclamate, which was widely used in dietary foods and beverages, could induce cancer in rodents if given in inassive doses. ${ }^{16}$ The ensuing FDA ban of cyclamates and the attendant publicity inflicted substantial economic injury to packers who had products already processed with the sugar substitute. ${ }^{17}$

Another source of increasing difficulty is the growing sophistication of analytical clemistry. At the time the law was enacted toxicologists were able to detect adulteration on the order of one part of adulterant per million parts of sample. ${ }^{18}$ Today's analytical procedures for specific substances have attained sensitivities on the order of one part

12. See Debate, supra note 9 , at 588, and text accompanying notes 44-52 infra.

13. Debate, supra note 9 , at 589 .

14. In 1970, 330,840 Americans died of cancer. U.S. DeP'T of CoMMERce, SoCial and Economic Statistics Administration, Bureau of the Census, 1972 StatisTICAI ABSTRACT OF the UNTred-States 59 (Table 80). Of the persons now alive in the United States, 52 million will die from cancer unless new methods of prevention or cure are found. National Health Educataon Committee, Inc., Facts on the MaJOR KIlling aNd CRIPpling Diseases IN the UnIted States Today (What Are the Facts about Cancer) 1-2 (1971). The yearly economic loss to individuals and the federal government is about $\$ 15$ billion. Id. at 2 .

15. Debate, supra note 9, at 589, 591. See also testimony of Dr. W.C. Hueper, Food Additives, Hearings Before a Subcomm. of the Comm. on Interstate and Foreign Commerce, 85th Cong., 2d Sess., at 369-72 [hereinafter cited as 1958 Hearings]; testimony of Dr. Francis E. Ray, id. at 199-206. This testimony is briefly discussed in the text aceompanying notes 158-65 infra.

16. Regulation of Food Additives and Medicated Animal Feeds, Hearings Before a Subcomm. of the House Comm. on Gov't Operations, 92d Cong., 1st Sess., at 5 [heremafter cited as Food Additives Hearings]. See also 224 Nature 398-99 (1969).

17. NewsweEk, Nov. 3, 1969, at 73-74.

18. See Fishbach, Problems Stemming From the Refinement of Analytical Methods, 18 Food DRUG CosM. L.J. $459-68$ (1963). 
per billion ${ }^{19}$ and are well on their way to sensitivities on the order of one part per trillion. ${ }^{20}$ Naturally, the more rigorous the inspection, the greater the probability that a particular food item will be found to be contaminated.

An illustration of the way increasing assay sensitivity complicates the task of the FDA can be found in the agency's attempts to regulate the use of DES. This substance is a nonsteroid synthetic estrogen ${ }^{21}$ which found wide application in the fattening of both poultry and cattle. ${ }^{22}$ Since estrogens were known to be carcinogemic, the FDA required that DES be administered in such a way that no residue would appear in edible portions of meat animals. ${ }^{23}$ "No residue," however, means no detectable residue. In the late 1950's improved assay methods revealed chicken liver contamination on the order of 25 to 50 parts per billion (ppb), and the use of DES in poultry was suppressed. ${ }^{24}$ In 1972, spurred to heightened vigilance by pressure from Congress, the FDA detected $1 \mathrm{ppb}$ levels of DES in beef liver. ${ }^{25}$ Oral administration of DES to cattle was promptly prohibited. ${ }^{26}$ Finally, in 1973, liver DES levels of $0.120 \mathrm{ppb}$ were uncovered, ${ }^{27}$ and the order banning ear implants was prounulgated. ${ }^{28}$

This process has no theoretical limit, and it is quite conceivable that with continuing improvements in assay techniques, most of today's agricultural or processing practices will be found to contaminate foodstuffs with impermissible substances. At present it is still legal

19. See National Research Council Report, "No Residue" and "Zero Tolerance," 20 Food DRUG Cosm. L.J. 608, 612 (1965).

20. Debate, supra note 9, at 589.

21. See A. White, P. Handler \& E. Smith, Principles of Biochemistry 1067 (5th ed. 1973).

22. Bell v. Goddard, 366 F.2d 177, 178 (7th Cir. 1966); Food Additives Hearings, supra note 16 , at 175 .

23. See note 5 supra. It has been shown that massive doses of DES were carcinogenic for females who were exposed to the drug before birth when it was administered to their mothers. Greenwald, Barlow, Nasca, \& Burnett, Vaginal Cancer After Maternal Treatment with Synthetic Estrogens, 285 NEw ENGLAND J. MED. 390 (1971); Herbst, Ulfelder, \& Poskanzer, Adenocarcinoma of the Vagina: Association of Maternal Stilbestrol Therapy with Tumor Appearance in Young Women, 284 NEW ENGLAND J. MED. 878 (1971).

24. Bell v. Goddard, 366 F.2d 177, 179-81, 183 (7th Cir. 1966).

25. The 1 ppb contamination "detected" by the FDA was actually an FDA extrapolation from data obtained by USDA. DES Hearings, supra note 4, pt. 3, at 357 . The pressure from Congress is exemplified by Congressinan Fountain's concluding remarks at the close of his coinmittee's March 30, 1971, hearings. Food Additives Hearings, supra note 16, at 590-91. It is also revealed by the tenor of his questioning at the November 11 and December 13 hearings and the nature of the documents which he submitted for the record. DES Hearings, supra note 4, pts. 1 \& 2.

26. DES Hearings, supra note 4, at 354-59.

27. N.Y. Times, supra note 3.

28. See text accompanying notes 1-3 supra. See also Fed. Reg. 11299-11301 (1974). 
for a farmer to paint his barn or a packer to oil the wheels on his canning line, but under the letter of the law even these practices could be challenged if it could be shown that oil or paint produced cancer in test animals. ${ }^{29}$

It is in the future, however, that real conflict is expected. Expansion of the market for convenience foods is expected to increase sharply the demand for food additives, while constantly improving assay techniques threaten the legality of many currently existing production and processing practices. ${ }^{30}$

In recognition of these problems, the Department of Health, Education and Welfare (HEW) reportedly developed a strategy designed to weaken the law's impact without appearing to be coming to the aid of food adulterators. ${ }^{31}$ The strategy called for recommending amendment of the law to allow administrative discretion in setting permissible tolerance levels, while at the same time appearimg to einphasize consumer protection by broadening its scope to include mutagens and teratogens as well as carcinogens. ${ }^{32}$ HEW's strategy, however, appears to have backfired spectacularly. Instead of abandoning the no-compromise policy of the clause, a bill introduced in the last Congress simply expanded it to cover mutagens, teratogens, and other substances known to cause "chromic biological injury." wards, who was then commissioner of the FDA, pointed out, most substances fall in the latter category, including such common ingredients as salt and sugar. ${ }^{34}$

Marked by failure to exercise the necessary scientific foresight, the history of the Delaney clause provides an object lesson on the difficulties that lie in the way of developing rational regulation of technological advances. In this sense, the lessons to be gained from the debate surrounding the clause go beyond the question of what ought to be permitted in the food supply. Moreover, the clause demonstrates how easy it is for the intent of the legislature to be thwarted by personal pohtics and unrestrained advocacy.

The clause was enacted following some of the most extensive legislative learings in the history of Congress. ${ }^{35}$ The deliberations which gave rise to the statute were aided by the counsel of scientists of

29. See text accompanying notes $96-98$ and 122-23 infra.

30. Uncertain Threat, supra note 9, at 666.

31. Debate, supra note 9, at 591.

32. Id.

33. S. 76, 92d Cong., 1st Sess. (1971).

34. San Francisco Examiner, Sept. 20, 1972, at 2, col. 2.

35. The Senate Labor and Public Welfare Committee, in writing the Food Additives Amendment's legislative history, stated that the bill represented the culmination of "the most extensive and intensive hearings on legislative proposals in a particular field of which we have knowledge." 1958 U.S. CODE CONG. \& AD. NEws 5302. 
national renown. The policy's execution was entrusted to a respected regulatory agency whose personnel unquestionably possess great technical expertise. The statute which was enacted could hardly have been nrore simple; there are no difficult doctrinal problems in its construction, and there has been little case law distorting or extending its nreaning. Furthermore, the scientific issues underlying the clause's policy are relatively simple to analyze. Yet something went wrong.

The following analysis of the controversy surrounding the Delaney clause first considers the language of the law itself and its judicial construction. A second section evaluates the scientific neerits of the law's policy, concluding on the basis of scientific criteria ${ }^{36}$ that the clause, if read hiterally, is irrational and its policy inappropriate. How a statute unreasonable on its face came to be adopted is the topic of a third section. Finally, a number of conclusions are drawn about the nature of the controversy as it exists today, and recommendations are nrade about the role lawyers can play in lielping to prevent repetition of the errors which led to the clause's enactment.

\section{The Delaney Clause: Text and Context}

\section{A. The Statute Itself}

The Delaney clause is found in section 348 of title 21 of the United States Code, which in general establishes the procedure and criteria for licensure of food additives. Enacted as part of the Food Additives Amendment of 1958, ${ }^{37}$ section 348 prohibits (within the reach

36. Other criteria, of course, are also relevant. Considerations of administrative simplicity, for example, may favor the present rule barring all discretion. Admimistrative efficiency, however, is purchased at a cost that includes public health risks, economic losses, and forgone opportunities to improve the food supply by applying modern technology. See text accompanying notes 3 and 16-17 supra, and 112-15 infra.

37. Pub. L. No. 85-929, 72 Stat. 1783 (1958). The Amendment originated in the House of Representatives as H.R. 13254, following exceptionally protracted hearings. 1958 U.S. CODE CONG. \& AD. News 5302. The law made two distinct changes in the FDCA. First, it legalized the heretofore impermissible practice of intentionally adding toxic substances to food. See 21 U.S.C. $\$ \S 342$ and 346 (1970). Second, it required that manufacturers test additives for toxicity and submit the data to the government for issuance of regulations prescribing permissible conditions of use. 21 U.S.C. $\$ 348$ (a) (1970). The testing requirement, however, was waived for items on the "generally recognized as safe" (GRAS) list. In addition, the Amendment redrafted related sections of the FDCA so as to give effect to the new scction. For example, subsection (s) defining food additive was added to section 321 , and sections 342 and 346 were amended to except licensed food additives from those "added poisonous or added deleterious" substances whose presence made food illegally adulterated. 21 U.S.C. $\$ \S 321,342,346$ (1970). 
of the commerce clause) use of an additive unless first authorized by the Secretary of Health, Education and Welfare. ${ }^{38}$

The Delaney clause provides that "no additive shall be deemed to be safe if it is found to induce cancer when ingested by man or animal, or if it is found, after tests which are appropriate for the evaluation of the safety of food additives, to induce cancer in man or ammal . . .."30

A food additive is defined in section 321 (s) as:

any substance the intended use of which results or may reasonably be expected to result, directly or indirectly, in its becoming a coinponent ... of any food (including any substance intended for use in producing, manufacturing, packing, processing, preparing, treating, packaging, transportation, or holding food . . .), if such substance is not generally recognized, among experts qualified by scientific training and experience to evaluate its safety, as having been adequately shown through scientific procedures . . . to be safe under the conditions of its intended use . . . .40

Section 321 defines "safe" as referring to the health of man or animal. Section 321(f) defines "food" to inean the food of man or animals.

The breadth of sections 321(s) and 321(f) had the initial effect of applying the Delaney clause to additives of animal feeds. As a result, certain drugs, like DES, were legal to administer to an animal paren-

38. The party applying for permission to employ an additive must provide a variety of information including the results of "investigations made with respect to the safety for use of such additives . . ."21 U.S.C. $\$ 348(b)(2)(E)(1970)$. This requirement shifted the burden of proof from the government to the proponent of the additive. Previously, the manufacturer was not required to demonstrate safety before marketing a product; instead, the government was required to demonstrate hazard afterwards.

Section 348 also provides:

(a) A food additive shall, with respect to any particular use or intended

use . . . , be deemed to be unsafe. . . , unless-

(2) there is in effect, and it and its use . . . are in conformity with, a regulation issued under this section prescribing the conditions under which such additive may be safely used."

Id. $\S 348(\mathrm{a})$. Pursuant to section $348(\mathfrak{a})$, an unsanctioned additive is deemed unsafe for the purposes of section $342(a)(2)(C)$. Since section 342 states that "[a] food shall be deemed to be adulterated . . . if it is, or it bears or contains, any food additive which is unsafe within the meaning of Section 348 . . , an unlicensed additive makes a product adulterated. Id. $\S 342(\mathrm{a})(2)(\mathrm{C})$. And as one might expect, it is illegal to do business in adulterated food. Section 331 states:

The following acts and the causing thereof are prohibited:

(a) The introduction or delivery for introduction into interstate coinmerce of any food . . . that is adulterated . . . .

(b) The adulteration . . . of any food . . . in interstate commerce. ated...

(c) The receipt in interstate commerce of any food . . . that is adulter-

Id. $\S 331$.

39. Id. $\$ 348(\mathrm{c})(3)(\mathrm{A})$.

40. Id. $\S 321(\mathrm{~s})$. 
terally but were illegal to give by mouth. To rectify this inconsistency, section 348(c)(3)(A) was amended in $1962^{41}$ to read:

[N]o additive shall be deemed to be safe if it is found to induce cancer .... except that this proviso shall not apply with respect to the use of substances as an ingredient of feed for animals which are raised for food production, if the Secretary finds . . . that no residue of the additive will be found . . . in any edible portion of such animal after slaughter or in any food yielded by or derived from the living animal ....42

The use of DES to fatten cattle was technically not regulated by the clause. Nevertheless the policy of the clause-that no trace of a carcinogen be permitted in the finished food product-was controlling for the use of the hormone. The policy and the exact language of the clause were extended to "new animal drugs" by section $360 \mathrm{~b}$ (d)(1) $(\mathrm{H}){ }^{43}$ This section makes it impossible for the Secretary to approve a new animal drug which is a carcinogen unless no trace of it will appear in any food derived from treated animals. Thus section 348(c)(3) (A) together with section $360 \mathrm{~b}(\mathrm{~d})(1)(\mathrm{H})$ applies the no-tolerance policy to substances administered to food animals as either feed additives or parenteral drugs.

Section 348 limits HEW's administrative discretion in granting approval of particular additives:

The Secretary shall ... by order establish a regulation ... prescribing, . . . the conditions under which such additive may be safely used (including . . . the maximum quantity which may be used or permitted to remain in or on such food . . ...44

The executive is forbidden to permit use "if a fair evaluation of the data before the Secretary . ..$^{45}$ fails to establislı that the proposed use of the food additive, under the conditions of use to be specified . . . will be safe-Provided, that no additive shall be deemed to be safe if it is found to induce cancer . . . .".46

The issue of tolerances raised in section $348(\mathrm{c})(1)(\mathrm{A})$ receives further attention in section 348 (c) (4):

If, in the judgment of the Secretary, . . . a tolerance limitation is required in order to assure that the proposed use of an additive will be safe, the Secretary . . . shall not fix such tolerance limitation at a

41. Pub. L. No. 87-781, 76 Stat. 780 (1962).

42. 21 U.S.C. $\$ 348$ (c) (3)(A) (1970).

43. This was accomplished by the Animal Drug Amendments of 1968, Pub. L. No. 90-399; the ear implants used to administer DES to cattle, now prohibited, were "new animal drugs" for purposes of the statute. See id. $\$ \S 360(b)(a), 360(b)(d)$, $360(\mathrm{~b})$ '(e), 360(b)(f).

44. Id. \& $348(\mathrm{c})(1)(\mathrm{A})$.

45. Id. $\S 348(\mathrm{c})(3)$.

46. $I d . \S 348(\mathrm{c})(3)(\mathrm{A})$. 
level higher than he finds to be reasonably required to accomplish the

.. . effect for which such additive is intended . . . .47

Finally, section 348(c)(5) contains some highly particular instructions on criteria to be used in formulating use-granting regulations:

In determining, for the purposes of this section, whether a proposed use of food additive is safe, the Secretary shall consider ainong other relevant factors-

(A) the probable consumption of the additive ... ;

(B) the cumulative effect of such additive in the diet . . . taking into account any . . . related substance . . . in such diet; and

(C) safety factors which in the opinion of experts qualified by scientific training and experience to evaluate the safety of food additives are generally recognized as appropriate for the use of animal experimentation data. ${ }^{48}$

Thus, while section 348 authorizes the supervised use of potentially harmful food additives, Congress chose to restrict sharply the FDA's administrative discretion in connection with their use. Not only is the administration forbidden to permit use of even the smallest ainounts of carcinogens, but the standards and procedures for regulation of additives are also dictated.

This lack of discretion contrasts sharply with that afforded by the related section 346, which directs the Secretary to set tolerances in food for "poisonous or deleterious substances" 49 which are added to food but which are required or whose addition cannot be avoided. ${ }^{60}$ Section 346 is considerably more permissive of administrative discretion. It states that "when such [toxic] substance is . . . required or cannot be ... avoided, the Secretary shall promulgate regulations limiting the quantity therein . . . to such extent as he finds necessary for the protection of public health ...." In Indeed, the only restraints on discretion are these:

In determining the quantity of such added substances to be tolerated ... the Secretary shall take into account the extent to which the use of such substances is required or cannot be avoided . . . and the other

47. Id. § $348(\mathrm{c})(4)$.

48. Id. $\S 348(\mathrm{c})(5)$.

49. Id. § 346 .

50. Such substances are not food additives. Section 346 provides "Any poisonous or deleterious substance added to any food, except where such substance is required in the production thereof or cannot be avoided by good manufacturing practice shall be deemed to be unsafe ...." Id. $\S 346$. And section $342(\mathrm{a})(2)(A)$ provides that a food is deemed adulterated "if it . . . contains any added poisonous or added deleterious substauce (other than one which is ... (ii) a food additive ...) which is unsafe within the meaning of section $346 \ldots$. Id. $\$ 342(\mathrm{a})(2)(\mathrm{A})$.

51. Id. § 346 . 
ways in which the consumer may be affected by the same or other poisonous . . . substances. ${ }^{52}$

With respect to noxious substances themselves, section 346 is thus more permissive of unavoidable or necessary ingredients than section 348 is of intentional additives. This is an understandable distinction. There are, however, no instructions to HEW in section 346 to test unavoidable ingredients of specific classes of food for toxicity. Consequently, grave hazards from conventional foods may go unexplored while the FDA grapples with evaluating the minor risks of novel intentional additives.

Section 342, the basic adulterated-food section, sets an even lower standard for foods whose deleterious substances are inherent and not added. It states:

A food shall be deemed to be adulterated ... [i]f it bears or contains any poisonous or deleterious substance which may render it injurious to health; ${ }^{53}$ but in case the substance is not an added substance such food shall not be considered adulterated . . . if the quantity of such substance . . . does not ordinarily render it injurious to health . . . .54

\section{8.}

Ostensibly, accidental contaminants are not regulated by section

[S]ubstances which may accidentally get into a food, as for example, paints or cleaning solutions used in food processing plants, are not covered by the legislation. These additives are generally referred to as "aecidental additives," since these substances if properly used may not reasonably be expected to become a component of a food . . . . If accidental additives do get in food, the provisions of the Food, Drug, and Cosmetic Act dealing with poisonous and deleterious substances would be applicable. ${ }^{55}$

The difficulty with this qualification is that reasonable expectations are conditioned by the degree of admixture one is willing to call "contamination." As was observed earlier, if a sufficiently sensitive method of analysis is used, it is to be expected that food will be found to be contaminated by virtually every object with which it has been in close proximity. A galvanized milk can dissolves, ever so slightly, in each portion of milk it contains. ${ }^{56}$ Even a properly painted barn contami-

52. Id.

53. The exceptions to this rule are also found in section 342. See note 50 supra.

54. 21 U.S.C. $\$ 342$ (a)(1) (1970).

55. Legislative History of the Food Additives Amendment of 1958, 1958 U.S. Code Cong. \& AD. News 5304 (emphasis added). The sections referred to would appear to be sections 342 and 346 .

56. A galvanized can is iron, coated with a metalic zinc surface. The galvanic couple between oxidized iron and zine metal and the direct air oxidation of the zinc itself soon forms a surface coating of $\mathrm{ZnCO}_{3} \cdot 3 \mathrm{Zn}(\mathrm{OH})_{2}$. In ordinary language, it 
nates the milk collected there, and this contamination becomes a "reasonable expectation" as soon as ultrasensitive assays become available. $^{57}$

\section{B. Judicial Construction}

Unfortunately, any hope that the courts will prevent unreasonable results by narrow statutory construction of the clause is probably unfounded. To the contrary, it seems likely that courts will give as liberal a reading to the statute as they perceive to be necessary to protect public health. For example in United States v. 41 Cases More or Less, ${ }^{58}$ the leading case to date on the meaning of section $321(\mathrm{~s})$, the Fifth Circuit lield that "[t] $]$ he sole criterion for identifying a food additive is whether a substance which may become a component of or affect the characteristics of any food be not generally recognized among qualified experts as having been shown to be safe ...."50 The court rejected the appellant's contention that the term "food additive" is reserved under the statute to substances not generally recognized by experts as safe under the conditions of intended use. "The courts have been reluctant to give too narrow a construction to this statute simce it touches public health." 60

In spite of the dearth of instances in which courts have found occasion explicitly to enforce the clause, ${ }^{81}$ it is obvious that the policy of the clause will prove to be influential. In Bell v. Goddard, ${ }^{02}$ for example, the Seventh Circuit sustamed an FDA order prohibiting use of DES to fatten chickens. Authority for the order was founded not on the clause but rather on FDA discretion to find on the basis of substantial evidence that use of a drug was unsafe. The drug's proponent evidently made a vigorous and scientifically well-reasoned argument for the drug's safety as used. Reproduction of this argument in the

tarnishes. These zinc compounds are sparingly water soluble (e.g. for $\mathrm{Zn}(\mathrm{OH})_{2}$ itself, Ksp $=5 \cdot 10^{-17} \mathrm{M}$ at $18^{\circ}$ ) and hence dissolve in the milk to a minute extent. E. Singh, Modern Inorganic Chemistry 264-65 (10th ed. 1961); Z. W. Linke, SOLUBILITIES 1673 (1965).

57. See Fishbach, Problems Stemming from Refinement of Analytical Methods, 18 Food DRUG COSM. L.J. 459-68 (1963).

58. 420 F.2d 1126 (5th Cir. 1970).

59. Id. at 1131 .

60. Id.

61. Indeed, there apparently has not been a case in which the Delaney clause itself was directly construed. But cf. note 62 infra.

62. 366 F.2d 177 (7th Cir. 1966). In Bell, which appears to be the only opinion interpreting the clause, the court stated in dictum that the Delaney clause "is generally intended to prohibit the use of any additives which under any conditions induce cancer in any strain of test animal." Id. at 181. This case was an appeal from a 1959 order of the FDA suppressing use of a particular proprietary formulation of DES for use in chemically castrating or feminizing chickens in order to produce "caponettes." (Surgically castrated chickens are nnarketed as "capons.") Petitioner's claim that the FDA's 
opinion $^{63}$ suggests that the court understood the reasoning and afforded it close scrutiny. Yet the court wrote:

In sum, the petitioner contends that there is no evidence in the record which demonstrates that exposure to caponette [DES] residues in any maximum likely quantity would have any harmful physiological effect.

The answer to the petitioner's contentions in great part is that DES is definitely a cause of cancer in animals, at least an inciter of malignant cancer in man, and possibly a cause of cancer in man. ${ }^{84}$

In effect, the court in construing another statute was guided by the policy of the Delaney clause that to demonstrate the carcimogenicity of an agent forecloses any further consideration of its safety as an intentional component of food.

Another example of the respect courts may be expected to give the clause is afforded by Environmental Defense Fund, Inc. v. Ruckelshaus, ${ }^{65}$ one of the cases resulting from efforts of environinentalists to suppress the use of DDT. In an earlier action ${ }^{68}$ the plaintiffs liad sought to require HEW to set zero tolerance for DDT on agricultural products under authority of the Delaney clause, on the grounds that DDT was a carcinogen. The court found, however, that DDT was not a food additive under section 321(s). ${ }^{87}$ In Ruckelshaus, their approach was to challenge the Secretary of Agriculture's judgment in failing to find that the carcinogenicity of DDT in animals inade it unsafe for contimued use on human food. The court stated that it had neither the evidentiary record nor the scientific expertise to permit review of the Secretary's findings. ${ }^{68}$ In a note, however, the court expressed its willingness to read the policy of the Delaney clause into the statute regulating insecticides. ${ }^{99}$

Petitioners contend that because DDT has produced cancer in test animals, the Secretary is compelled as a matter of law to infer that there is a high probability that it causes cancer im man. That inference

action was impermissible as a retroactive application of the Delaney clause was rejected and the order was upheld under section 355(e), as it was then in effect, which empowered the FDA to suppress a new drug if its use was unsafe. (The section was amended in 1962. Pub. L. No. 87-781, 76 Stat. 780 (1962).) The court found that testimony that DES was a carcinogen would sustain the FDA's conclusion its use was unsafe. 366 F.2d at 182. Thus the court was not required to reach the meaning of the Delaney clause in order to dispose of the case before it.

63. 366 F.2d 177, 181-82 (7th Cir. 1966).

64. Id. at 182 .

65. 439 F.2d 584 (D.C. Cir. 1971).

66. Environmental Defense Fund, Inc. v. United States Dep't of HEW, 428 F.2d 1083 (D.C. Cir. 1970).

67. 428 F.2d 1083, 1091.

68. 439 F.2d $584,596$.

69. 7 U.S.C. \& 135 (1970). 
is of course not compelled by the Delaney Amendment . . . because [it] applies only to food additives .... . The Amendment does, however, indicate the magnitude of Congressional concern about the hazards created by carcinogenic chemicals, and places a heavy burden on any administrative officer to explain the basis for his decision to permit the continued use of a chemical known to produce cancer in experimental animals. ${ }^{70}$

\section{Summary}

Section 342 is the basic statute forbidding commerce in adulterated food. It sets out that food shall be considered adulterated if it contains deleterious substances in sufficient quantity to make it ordinarily injurious to health, no matter how the substance came to reside within the food. Moreover, food will be considered adulterated if it contains any quantity of an intentionally or inadvertently added deleterious substance unless the substance is either a food additive (or pesticide, color additive, or new animal drug) which is deemed safe by virtue of licensure under section 348 or a deleterious substance which is deemed to be required or unavoidable in production of food under section 346. Under the operation of both sections 346 and 348 , the amount of the deleterious substance which food may contain is limited by tolerance levels set by HEW.

The Delaney clause forbids licensure of all carcinogens under section 348 and makes it illegal to add carcimogens to food in any quantity. Since under section 321(f) "food" ineans the food of man or animals, the clause would apply to food additives for animals if it were not for a 1962 amendment suspending operation of the clause with respect to animal feed. The amendment, however, applies the zero tolerance level policy ${ }^{71}$ of the clause to the human food derived from ammals whose food was exempted from the clause proper. Similarly, the policy of the clause is extended by section $360 \mathrm{~b}(\mathrm{~d})(1)(\mathrm{H})$ to food derived from animals treated with carcinogemic new animal drugs. Moreover, it is proposed to extend zero-tolerance to mutagens, teratogens, and substances causing chronic biological injury. ${ }^{72}$

II

Scientific ANalysis of the Policy of the Delaney Clause

\section{A. Causation}

Unquestionably, the policy of the Delaney clause has great appeal to the common sense and eniotions of the average person. If carcino-

70. Environmental Defense Fund, Inc. v. Ruckelshaus, 439 F.2d 584, 596 n.41 (D.C. Cir. 1971).

71. The clause disallows licensure, which means that the substance must have zero tolerance pursuant to section 342 .

72. See note 33 supra and accompanying text. 
gens cause cancer, then to avoid cancer one must only avoid carcinogens; conversely, failure to avoid carcinogens results in a failure to avoid cancer. Even in addressing the presumably sophisticated audience of Science, editor Nicholas Wade seems to have felt the need to ask rhetorically: "Why so much heat about a law which says only that cancer-causing substances shall not be allowed in people's food?"73

But such reasoning is scientifically naive at best and dangerously misleading at worst. The phrase "causes cancer" in reality has several meanings, ${ }^{74}$ among them ones so far removed from the commonsense understanding of the words that to give them effect in a statute may prove counterproductive to public health. In ordinary usage a cause is the necessary and sufficient precedent of its effect. ${ }^{75}$ This sense of "causation," however, has little utility for the scientist, and except in very informal parlance the results of scientific analysis seldoin find expression in such terms. What scientific analysis yields is simply a description of past experience, generally the results of some set of observations, experiments, or operations. ${ }^{78}$ These results are almost always expressed in terms of a quantitative relationship between an imdependent variable (a "cause") and its dependent variable (the "effect"). ${ }^{77}$ Science thus deals not with cause and effect in the ordinary sense but with the magnitude of "effect" to be expected from some given quantity of "cause." 78 For example, Ohm's law does not state that voltage "causes" current but rather that the magnitude of current is directly proportional to the magnitude of voltage.

Such relationships among variables are, however, only the beginning of scientific analysis. Any given relationship is only valid for some set of invariant conditions. ${ }^{79}$ The magnitude of an "effect" corresponds with our expectations only if no other factors which influence the effect are altered. For example, the pressure of a perfect gas doubles when its volume is reduced by half, but only if the temperature of the gas remains constant. If the temperature increases, the pressure will more than double, since pressure is proportional to absolute temperature as well as inversely proportional to gas volume. In reality, then, any particular effect has numerous "causes." The observed effect is the suin of all contributing causes.

73. Debate, supra note 9 , at 588.

74. Cf. N. Campbell, What is SCIEnce? 39-40 (1952).

75. Id. at 49-50; see J. TOWNSEND, INTRODUCTION to Expertarental METHOD 18 (1953).

76. J. Kemenx, A Philosopher looks at Science $50-51$ (1959); see N. CAMPBELL, supra note 74 , at 50-52; J. TownSEND, supra note 75 , at 16-17.

77. J. TOWNSEND, supra note 75, at 52-53.

78. N. CAMPBELL, supra note 74, at 52-54 (1952); cf. J. KeMENY, supra note 76, at $50-51$.

79. See J. TowNSEND, supra note 75, at 57, 64-67. 
Moreover, the extent to which an effect is influenced by a change in any particular cause may itself depend upon the magnitude of other causes. In more precise terms, the relationship between two variables may itself be a function of the value of a third variable. ${ }^{80}$ Pressure of real gases, for example, continues to increase with decreasing gas volume only at temperatures above the critical temperatures. Below the critical teinperature, continued compression ultimately causes liquefication of the gas. At the point of liquefication reduction in volume causes no further increase in pressure, but only increases the proportion of liquid to vapor. Hence the dependence of pressure on volume is itself dependent upon temperature. A scientific description of "causation," therefore, is simply that under some specific unchanging set of conditions, one factor alone was altered and there followed soine particular change in another factor. ${ }^{81}$

What has the foregoing to do with the causes of disease? To an experimental biologist, the "cause" of a disease is any factor whose increasing magnitude is accoinpanied by increasing incidence or severity of the disease in the experimental population. Thus, if inbreeding of experimental animals results in offspring of heightened susceptibility, then genetic factors "cause" the disease. If in other experiments with the same disease, increasing the number of animals housed in each cage is accompamed by increased incidence, then crowding "causes" the disease.

When physicians speak of the cause of a disease in a human population, they generally mean the one particular factor-among all those that the experimentalist might find-that is easiest to mamipulate to lower the incidence of the disease or to palliate its effects in individual patients. Thus the causes of fatal falciparuin malaria are (1) the failure to inherit sickle cell trait from one's parents, (2) followed by the failure to ingest anti-malarial drugs such as quinine, (3) followed by exposure to the bite of the female of a particular species of mosquito which happens (4) to harbor a particular protozoan parasite (5) previously acquired by the mosquito in the course of feeding on the

80. In mathematical notation:

$$
\frac{\partial^{2} y}{\partial x \partial z} \neq 0 .
$$

81. Strictly speaking, however, even such a limited concept of causation is not what science describes. In very few instances will the dependence of the effect upon the cause be precisely and reliably recurrent. Rather, the dependent variable will fluctuate around the value it would have if the theoretical relationship were completely accurate. Sometimes this imprecision is attributable to error, sometimes to the fact that the relationship is only a rough generalization about the average behavior of a multitude of independent entities. But whatever the source of the observed discrepancy, the regularity is only a statistical generalization which states that given some value of "cause," the "effect" will probably fall within a certain predicted range of values. See generally J. KEMENY, supra note 76, at 72-81, 158. 
parasite's former warm-blooded host. ${ }^{82}$ To the physician whose patients are unavoidably exposed to infected mosquitoes it is the failure to take quinine which causes the disease, since this is the point in the causal chain that is most vulnerable to his intervention. Other health professionals would tend to see the problem in different terms. For example, to public health specialists charged with draining swainps and spraying mosquito larvae, the cause of malaria is the unrestrained reproduction of the mosquito.

From this perspective, how are we to understand the concept of cancer induceinent that appears in the Delaney clause? ${ }^{83}$ If the clause is interpreted narrowly, so as to forbid addition to food of substances whose presence or absence will materially affect the incidence of cancer in the human population, it would take a hardy exponent of food additives to voice an objection. But if the clause is read to proscribe any substance that can be used in some particular experimental design to augment, if ever so shightly, the incidence of cancer in experimental animals, then the wisdom of the statute is surely open to question. Because it is far from certain that there exists any substance which cannot increase the incidence of cancer under some particular set of conditions in some specific strain of animals, the clause takes on the character of an open-ended invitation for experimentalists to outlaw essentially innocuous substances by finding the conditions which render thein harmful. Taking this view, dispute about the clause arises because its advocates understand cause in the sense of material contribution to the incidence of cancer, while its opponents insist that the statute turns upon a demonstration which may or may not be relevant to human health. Seen this way, the clause owes its political vitality to the commonsense, naïve perception of cause; and its capacity for mischief to the ultimate operational meaning of the word.

\section{B. Zero-Tolerance and The Dose-Effect Relationship}

1 Turning from the meaning of causation in the clause to its policy of zero-tolerance, even greater theoretical difficulties appear. Carcinogens are like all biologically active substances; they owe their effect to the manner in which they react ${ }^{84}$ with the chemical constituents of living organisms. ${ }^{85}$ For active substances in general, the greater the ex-

82. P. HoRpRICK, INFECTIOUS DISEASES 1113, 1120, 1124-25 (1972).

83. This portion of the clause is reproduced in the text accompanying note $39 \mathrm{su}$ pra.

84. "Reaction" is used here in the chemical sense; it means a conbination of two or more substances under the influence of physicochemical forces that yields products distinguishable from the reactants as distinct chemical species.

85. See generally A. Goldstein, L. Aronow \& S. Kalman, Principles of Drug Action 1-3 (1969) [hereinafter cited as Principles of DrUg Action]. It has been 
tent of reaction the greater the magnitude of effect. ${ }^{80}$ Moreover, - the response of a biological system to a physiologically active agent is proportional over some range of concentrations to the concentration of the active agent within the system..$^{87}$

With these principles in mind, it is possible to give a very simplified account of the probable influence of concentration of an active agent (an effector) upon the response of the organism in which it produces its effects. It is postulated that the analysis is valid for carcinogens. At any particular concentration of effector-that is, at any given ratio of amount of active agent to the size of the organism-an agent may undergo a variety of different reactions with various constituents of the organism (receptors).$^{88}$ Some of these reactions proceed slowly, some rapidly, some lead to destruction or excretion of the effector, others so alter the properties of the receptors that they produce an effect on the organism. The net effect seen in the organism is the sum of effects of each reaction into which the effector may enter.

The relative importance of each reaction in the total picture depends in part upon two characteristics of the reaction. If the products of the reaction in question never accumulate-for example, because they are excreted, destroyed, or passed to yet another reaction-the contribution this reaction makes to the total physiological response will depend in some measure upon how well it competes with other reactions which are simultaneously consuming the effector. Put another way, the importance of the reaction will depend, other things being equal, upon its velocity relative to the rate of competing reactions. ${ }^{80}$ If, on the other liand, the products of the reaction in question are allowed to accumulate so that the reaction approaches thermodynamic equilibrium, the contribution of the reaction will depend upon the extent to which the reaction has gone to completion. The extent of reaction (the ratio of receptor which has reacted with effector to that which has not), and thus the magnitude of effect, will vary with the inherent tendency of the reaction to occur-that is, with the magnitude of difference in free energy between the reactants and products. The latter relationship is the basis of the law of mass action. ${ }^{00}$

noted that every chemical carcinogen which has been thoroughly studied has been found to bind covalently with DNA, RNA, and protein of the target tissue. Jerma \& Daly, Arene Oxides: A New Aspect of Drug Metabolism, 185 ScIEnce 579 (1974).

86. See generally PRINCIPLEs of DRUg Action, supra note 85, at 70-72, 85.

87. Id. at 70-85. See also notes 90-92 infra.

88. See generally PRINCIPLES of DRUg ACTION, supra note 85, at chs. 1-4.

89. See generally PRINCIPLES OF DRUo ACTION, supra note 85 , at $95-96$.

90. Where $[E]$ is the concentration of effector, $[R]$ the concentration of receptor, [ER] the concentration of the product of the reaction of receptor with effector, and $\mathrm{K}$ a constant, then 
Another relationship which can be derived as a special case of this law has very great significance in physiological chemistry. The relationship states that the reciprocal of the magnitude of effect is directly proportional to the reciprocal of effector concentration; it is broadly applicable to the analysis of both enzyme activity and drug action. ${ }^{01}$

$$
\frac{[\mathrm{ER}]}{[\mathrm{E}][\mathrm{R}]} \cong \mathrm{K}
$$

This is exactly true for an ideal gas, if concentrations of reactants and products are replaced by partial pressures. Furthermore, if $\Delta G$ is the change in free energy, $R$ the universal gas constant, $T$ the absolute temperature, e the base of natural logarithms, and the concentration of effector receptor and product are replaced by their respective activities, $a_{E}, a_{R}$ and $a_{E R}$, then for any systein

$$
\log _{\mathrm{e}} \frac{\mathrm{a}_{\mathrm{ER}}}{\mathrm{a}_{\mathrm{E}} \mathrm{a}_{\mathrm{R}}}=\log _{\mathrm{e}} \mathrm{K}_{\mathrm{a}}=\frac{-\Delta \mathrm{G}}{\mathrm{RT}} .
$$

For the law of mass action see W. Moore, Physical Chemistry 168-174 (3d ed. 1962). For non-ideal systeins including solutions see $i d$. at 191-200. For dependence of $\Delta G$ on $\mathrm{K}$ see id. at 173-74, 191-200. For the application of the law of mass action to the effect of biologically active agents, see PRINCIPLES of DRUG ACTION, supra note 85, at 70-72.

91. This important relationship is derived from Michaelis-Menten theory. The Michaelis-Menten equations give the imitial velocity of an enzyme reaction as a function of substrate concentration. It may be written in the form

$$
\frac{1}{V}=\frac{K_{m}}{V_{\max }} \cdot \frac{1}{[S]}+\frac{1}{V_{\max }}
$$

where $V$ is reaction velocity, [S] is substrate concentration, $K_{m}$ is the Michaelis constant, and $V_{\max }$ is the maximal velocity. Since $V_{\max }$ and $K_{m}$ are constants, the equation is of the form

$$
\frac{1}{\mathrm{~V}}=\text { constant }_{1} \frac{1}{[\mathrm{~S}]}+\text { constant }_{2}
$$

The Michaelis-Menten equation is ordinarily applied to the initial velocity of reactions mediated by pure enzymes in dilute aqueous solution. It is a remarkable fact that the same relationship is found in a large number of cases to describe the dependence of biologic response upon drug concentration. In the latter instance, the equation takes the form

$$
\frac{1}{\Delta}=\frac{\mathrm{K}_{\mathrm{x}}}{\Delta_{\max }} \cdot \frac{1}{[\mathrm{X}]}+\frac{1}{\Delta_{\max }}
$$

where $\Delta$ is the magnitude of the biologic response, $\Delta_{\max }$ is the maximal response possible, $[\mathrm{X}]$ is the concentration of drug, and $K_{x}$ is a constant analogy to $K_{m}$.

The relationship may be valid even for the effect of a drug in a complex biologic systein. See M. Dixon \& E. Webr, Enzymes 63-70 (2d ed. 1964) (Michaelis-Menten theory); Principles of Drug ACtion, supra note 85, at 70-72 (derivation of relationship between biologic response and drug concentration) and 81-85 (general applicability of relationship).

Since Michaelis-Menten theory describes enzyme kinetics, its application to carcinogens is logically appropriate for those agents whose effect is enzymatically mediated. This class of bioactivated carcinogens is thought to include aromatic amines and AZO coinpounds, notrosamines, urethanes, carbon tetrachloride, aflatoxins and polycyclic aromatic hydrocarbons. See Jerma \& Daly, Arene Oxides: A New Aspect of Drug Metabolism, 185 SCIENCE 573, 579 (1974) (bioactivated carcinogens) and text accoinpanying notes 98-103 infra (carcinogenic polycyclic aromatic hydrocarbons). 
Wherever this relationship is obeyed, it provides a theoretical basis for making an initial prediction of the influence of effector concentration on physiological response. Such a prediction is, specifically, that the response increases in direct proportion to the concentration of effector until such a high concentration is reached that the availability of receptor begins to limit the reaction's sensitivity to effector concentration. In this range effect becomes proportional to the logarithm $^{92}$ of effector concentration. Finally, at very high effector concentration, the response becomes highly insensitive to further increases in effector concentration; the receptor is saturated with respect to that particular effector. ${ }^{93}$

Thus both the rate and the extent of completion influence a reaction's contribution to the physiological response. But the effect of concentrating the effector is the same. Increasing the concentration of effector within a certain range increases either the rate of reactions with receptor or the extent of reaction with receptor, thereby increasing the physiological response. ${ }^{04}$

Now it is possible to envision the response of an organism when it is exposed to increasing dosage of any particular agent. ${ }^{.5}$ As dosage is increased, all reactions of the effector will be increased and the effects produced will be auginented. At any particular concentration the chief or conspicuous effects of an agent will be those resulting from reactions which are efficient in use of the effector at that particular concentration. With increasing dosage previously inconspicuous reactions begin to make themselves felt. Concentrations are ultimately reached which saturate certain receptors. Thereafter, increasing dosage fails to increase the specific effect attributable to the receptors now saturated but tends to divert more and more effector to reactions previously unable to compete effectively with those now completed.

The overall result is that increasing the dosage of an agent produces qualitative differences in its effect. The practical result of these relations is that any substance, however innocuous or even necessary to the survival of an organism, becomes poisonous at some sufficiently high dose. This is true of salt, sugar, vitamins, and even pure water..$^{96}$ Conversely, every substance, no matter how noxious

92. PRINCIPLES OF DRUg Action, supra note 85 , at 77-85.

93. For the effect of very high and very low reactant concentrations on MichaelisMenten kinetics, see discussion of the integrated Michaelis equation in ENZYMES, supra note 91, at 114-16.

94. For the effect of concentration on rate of reaction, see E. DANIELs \& R. ALBerTy, Physical ChEMISTRY 326 (1955). Since [ER]/[E][R] is constant, addition of $\mathrm{E}$ to the system must be balanced by conversion of R to ER. See note 90 supra.

95. See generally PRINCIPLES OF DRUG ACTION, supra note 85, at chs. 2-4.

96. For example, pure water administered by gavage to albino rats may be lethal to half of the animals at a dosage of $469 \mathrm{ml}$ per $\mathrm{kg}$ body weight. E. BoxD, Predictive 
and potent it may be at some dose, becomes less and less toxic at lower and lower dosages.97 At a sufficiently low dosage-the threshold dosage which has been used to defend tolerance levels-its observed toxicity will disappear completely.

The foregomg discussion froms the basis for analyzing the concept of tolerance levels for chemical carcimogens. A chemical carcinogen is simply a substance that increases the incidence of cancer in exposed animals. It appears that, within limits, any given incidence of cancer may be achieved by applying high concentrations of weak carcinogens or low concentrations of strong carcinogens. If employed under specifically restricted conditions and at a sufficiently high concentration many substances, perhaps most, will prove carcinogemic. Conversely, even the most potent carcinogens becoine of little practical concern at sufficiently low dosage.

! Two studies illustrate the manner in which the action of chemical carcinogens conforms to well-known biochemical principles. In the first, Bryan and Shimkin studied the dose-response relation ${ }^{98}$ in mice for three carcimogenic substances. The agents used, methylcolanthrene (MCA), dibenzanthracene (DBA), and benzpyrene (BP), are paradigms of very high potency polycyclic aromatic hydrocarbon carcinogens. The results indicate, first, the same relationship exists between dose and response as that which applies to the response of animals to most drugs. ${ }^{99}$ Second, the imduction of cancer, even by these notoriously potent carcinogens, is uncertain at all doses below saturation doses. ${ }^{100}$ Third, the risk of developing cancer decreases steadily

Toxicometrics 90 (1972). Table sugar (sucrose) is lethal to half of recipient albino rats at a dose of 35.4 grams per $\mathrm{kg}$ body wcight. Id. at 257 . Table salt (sodium chloride) displays the same level of lethality at a dose of 3.75 grams per $\mathrm{kg}$ body weight. Id.

"All things are poisons, for there is nothing without poisonous qualities. It is only the dose which makes a thing a poison." Attributed to Paracelsus in PrInciples of DRUo ACTION, supra note 85, at 343.

97. Id. at 350-70.

98. Bryan \& Shimkin, Quantitative Analysis of Dose-Response Data Obtained with Three Carcinogenic Hydrocarbons in Strain C3H Male Mice, 3 J. NAT'L CANCER INST. 503-31 (1942) [hereinaftcr cited as Quantitative Analysis].

99. Id. at 527. The plot of tumor incidence, expressed in probits, against log of dose yields a straight line. For the significance of probits, see PRINCIPLES of DRUG AcTION, supra note 85, at 352-56. For MCA and DBA the relation was exact. Quantitative Analysis, supra note 98 , at 510,516 . For BP the data were heterogeneous but approximated linearity. Id. at 522 .

100. A fitted dose response curve for the data for the three agents can be represented by the following table.

Animals

Developing Tumors

(more than 1 year observation)

$5 \%$

$\begin{array}{ccc} & \text { Dose of } & \\ \text { DBA } & \text { Carcinogen in Micrograms } \\ 3 & \text { MCA } & \text { BP } \\ & 4.5 & 12\end{array}$


with the decreasing dosage for all dosage below saturation. ${ }^{101}$ Fourth, the agents differ among themselves with respect to their potency, at least with respect to the particular experimental design in which they were used. The dose of BP which induces cancer in 50 percent of treated animals is 6.3 times as great as the dose of DBA that produces the same incidence, a statistically significant difference. ${ }^{102}$

The three agents used in this first study are highly efficient carcinogens that are effective in producing cancer without assistance from special experimental regimes. ${ }^{103}$ Other carcinogens, however, are contingent or provisional in effect and low in potency. The second study, using the agent ethionine, illustrates the action of a carcinogen of this class.

Ethionine is an analog of the amino acid methionine, ${ }^{104}$ a common constituent of proteins. On the basis of knowledge of the relation of methionine to ethionine, ${ }^{105}$ it could be predicted a priori that ethionine in an ordinary diet would tend to be a relatively low-efficiency carcinogen, if one at all. Moreover, it would be expected that any capacity to induce cancer would be coinpletely suppressible by simultaneous administration of additional dietary inethionine. ${ }^{100}$

Farber has shown that ethionine induces hepatic carcinoma in the rat. $^{107}$ His studies suggest that ethionine is a very low efficiency carcinogen ${ }^{108}$ whose ability to cause cancer is contingent upon adminis-

$\begin{array}{cccc}50 \% & 16 & 21 & 101 \\ 95 \% & 84 & 96 & 875\end{array}$

Data for the three agents derived from Quantitative Analysis, supra note 98.

101. Id.

102. Id. at 524 .

103. This is not to discount the effect of so-called "promoters," which can amplify or condition the aetion of even highly effective agents such as those described in tho text. See Principles of Drug Action, supra note 85, at 673-75.

104. The analog differs from its more common congener only in the substitution of an ethyl for a methyl group. A. LeHNINGER, BIOCHEMISTRY 694 (1970).

105. Ethionine is a near universal antimetabolite which inhibits the growth of micro-organisms and animals. Like most analogs, however, its effects are attenuated by the compound it resembles. See Farber, Ethionine Carcinogenisis, 7 AdVANCES IN CANCER RESEARCH 383, 385-87, 414 (1963) [hereinafter cited as Farber].

106. Ordinary diets based on animal products contain substantial amounts of methionine. For example, the rats used in Farber's study were fed a diet containing 16 percent casein (milk protein), which contains 0.54 percent methionine. Id. at 417-18.

107. For a complete review of the action of ethionine, including ethionine carcinogenesis, see $i d$. at $383-474$.

108. In order to induce carcinomas in a majority of rats, it was necessary to administer ethionine as a 0.25 percent component of the diet for more than three months. A rough dose response relationship is represented by the following data:

Duration of DL-

$\begin{array}{ccc}\text { Incidence } & \begin{array}{c}\text { Ethionine Aduninistration } \\ \text { of Cancer }\end{array} & \begin{array}{c}\text { Months of } \\ \text { in Months }\end{array} \\ 0 / 9 & 1 & 17 \\ 3 / 8 & 2 & 17 \\ 4 / 10 & 3 & 17\end{array}$


tration in a diet which has not been fortified in methionine. ${ }^{109}$ Furthermore, the carcinogemicity of methionine is contingent in yet another sense. As the dose of ethionine is increased, acute toxicity of the agent begins to kill animals even before cancer develops. Put another way, the period of chromic administration required to imduce cancer exceeds the survival time under acute toxicity unless the dose is carefully selected. ${ }^{110}$

What is the ineaning of these studies for the regulation of food additives? The following is a concrete example which might aid in understanding their significance. If the milk supply of a town were found to be contanimated with $0.4 \mathrm{ppm}$ ethionine (100 micrograms per 8 ounces), one would be justified in being relatively unconcerned. Since milk contains $1000 \mathrm{ppm}$ methionine, the 2,500-fold excess of methionine would as a practical matter provide adequate protection. ${ }^{111}$ If, on the other hand, the milk supply were found to contain $0.4 \mathrm{ppm}$ of dibenzanthracene, one would be justified in making a very pessimistic prediction about the life expectancy of the community's children. ${ }^{112}$

\begin{tabular}{rrl}
\hline $4 / 10$ & 4 & 11 \\
$16 / 19$ & 5 & $11-13$
\end{tabular}

Id. at 420.

It is important here to contrast the efficiency of dibenzanthracene (DBA), effective in inducing sarcomas in 50 percent of mice when administered in a single dose of about 20 micrograms at a conceutration of perhaps $100 \mathrm{ppin}$, with that of ethionine, whose 50 percent induction dose appears from the above data to be daily administratiou for three months at a level of $2,500 \mathrm{ppm}$ in food (total dose more than 150,000 micrograms). Part of the disparity, of course, is attributable to strain differences and different methods of administration. Id. at 420 .

109. Auginentation of the diet (already 0.5 percent methionine) with additional inethionine antagonized the carcinogenicity of ethionine. The results were as follows:

Id. at 455 . Incidence of cancer during 8 months of administration

Methionine
in Diet $(+0.5 \%)$
$0 \%$
$0.3 \%$
$0.6 \%$
$0.8 \%$
of a $0.24 \%$ ethionine diet $17 / 18$
$5 / 10$
$0 / 9$
$0 / 9$

110. Id. at 419.

111. Milk is 3.5 percent protein. Nutrmional Data 106 (3d ed. 1956). Since a 16 percent casein (milk protein) diet is 0.5 percent methionine, see note 107 supra, milk is approximately $1000 \mathrm{ppm}$ methionine. Because a four-fold excess of nethionine blocks cancer induction by ethionine for eight inonths, see note 109 supra, a 2500 -fold excess could be regarded as providing a 600 -fold safety factor. (This is not to say, of course, that the ethionine would be totally harmless or that no carcinogenic effect could arise. Rather, it is to assert that the probability of untoward effects would be slight.)

112. In the study of Bryan and Shimkin, about 20 micrograms of DBA induced cancer in half of the mice when injected into the axillary space. See note 100 supra. The mice weighed 20-24 grams and the volune of solution injected was 0.25 to $0.5 \mathrm{ml}$. The dose of DBA can be regarded as either $1 \mathrm{nrg} / \mathrm{kg}$, on the basis of animal weight, or $40-80 \mathrm{mg} / \mathrm{kg}$, on the basis of vehicle volunie. In contparison, a child drinking one glass of DBA-contaminated milk per day for ten years would ingest $365 \mathrm{mg}$. If the child weighed 88 pounds at age 12 , the dose on the basis of body weight would be more 
By now it should be evident that not all encounters with carcinogens are equally harmful. Indeed, the line between carcinogens and noncarcinogens is itself indistinct. In fact, among those poisons for which tolerances can now be set under section 348 there may be substances like ethionine which will prove to be carcinogens only if experiments are done in such a way that those agents' acute toxic effects are masked long enough for chromic exposure to induce cancer.

In short, establishing the presence of a carcinogen in food is not very helpful unless its potency, concentration, and the conditions under which it is able to promote cancer are also considered. The policy of the Delaney clause foreclosing such consideration in the regulation of food production precludes bringing scientifically informed judgment to bear to protect the public food supply.

Sooner or later such a policy can be expected to injure the public interest. As the concentration of a carcinogen declines, the risk incident to consuming it falls. So may any potentiality the agent has for preserving health. If adding the agent to food has some life-protecting function, there probably comes a point at which further reduction of risk froin cancer by lowering the agent's concentration is more than offset by the increased risk from the danger against which the agent is protective.

The use of nitrites in such processed foods as canned ham, bologna and smoked fish furnishes a familiar exainple. In sausage foods nitrites are often used to improve color, an inadequate raison d'etre taken alone, since it is highly probable that nitrites give rise in the gastrointestinal tract to carcinogemic nitroso compounds. ${ }^{113}$ The bacteriostatic action of nitrites, however, is also highly significant. In particular, mitrites inhibit the growth of Clostridium botulinum and thus protect against botulism. ${ }^{114}$ Omission of nitrites may thus result in a substantial number of fatalities from botulism, ${ }^{115}$ perhaps affecting more

than $4 \mathrm{mg} / \mathrm{kg}$. For a vehicle volume calculation one would probably consider the entire dose to be dispersed in the volume of a single glass of milk, because the agent would have been ingested each day in an additional volume of milk only after the preceding day's volume had been absorbed. The dose thus calculated would be $1500 \mathrm{mg} /$ $\mathrm{kg}$. Finally, if it is assumed that the carcinogen would have been transported to the liver, as most ingested material is, a dose of $365 \mathrm{mg} / \mathrm{kg}$ could be calculated, assuming liver weight as $1 \mathrm{~kg}$. Regardless of the assumption made, it is apparent that the dose of DBA to the child's tissue would be significant in comparison to the dose which produced cancer in half the mice. 14.

113. Statement of Dr. W. Lijinsky, Food Additives Hearings, supra note 16, at 11-

114 Stateinent of FDA Commissioner Charles Edwards. Id. at 169-70.

115. In 1969 the FDA approved use of nitrite to aid in preventing growth of Clostridium botulinum type $\mathrm{E}$ in smoked chub (white fish). This action was provoked by three outbreaks of botulism traced to ingestion of Great Lakes smoked fish during 1960 . 69. Id. at 169-70. 
deaths by their absence than by their presence. The Delaney clause, unlike the rest of section 348 and all of section 346, prevents any balancing of risks against benefits in the use of nitrites and many other substances employed in food production.

The usual explanation for this disparity is that there is no such thing as a safe level for a carcinogen. Moreover, the effect of carcinogens (unlike that of other deleterious agents, Delaney clause supporters imply) is irreversible and cumulative; each increment of exposure, it is said, causes an increment of imjury. While this is undoubtedly true as an initial proposition, it is far from unique to carcinogens. The effects of acutely toxic substances are reversible only in the sense that recovery from the illness they provoke may be possible. Nevertheless, chronic exposure to most poisons causes imjury which ultimately exceeds the recuperative capacity of an organism and results in irreversible damage. The most familiar example is alcohol. Its acute effects are reversible but in chronic excess it causes permanent damage to stomach, liver, and braim. Thus reversibility alone does not distinguish carcinogens from other noxious substances.

There is, however, another nore fundamental difficulty with the explanation for singling out carcinogens. With respect to poisons whose effects are ordmarily reversible, the effect of a lethal dose is certainly irreversible. And with respect to carcinogens, if the exposed animal dies without getting cancer, the effect of the carcinogen is "reversed" by death. In other words, carcinogens cause a risk of death which continues indefinitely, while acute poisons cause a risk of death whose duration is limited. What really nuust be compared, then, in assessing the relative hazard of the two classes of agents is the total lifeshortening-occasioned on the one hand by a low probability of death extending over many years and on the other by a higher probability lasting but a short time.

Responding to this line of reasoning, it might be argued that a safe level can be stipulated for acute poisons, so there is no risk of death from exposure. The short answer is that there is no more an absolutely safe dose for an acute poison than there is for a carcinogen. Every increment of exposure to a deleterious substance raises the probability of death. ${ }^{116}$ This can be visualized by returning to the example of liquor. A single 11/2-ounce "shot" of whiskey is a "safe" dose, for an adult, far below the quantity which causes respiratory arrest in the average person. Nevertheless, for an ulcer patient the simgle slot may

116. This "no threshold" assumptiou is based upon the observation that individual sensitivity is normally distributed. PRINCIPLes of DRUG ACTION, supra note 74, at 352. It is also based upon the fact that effector-receptor reaction is described by the law of mass action. See note 91 supra. 
provoke a fatal hemorrhage. The problem of setting a tolerance level for a carcinogen is no different froin that of setting one for an acute poison. The level chosen is that which is perceived as creating no more than an acceptable risk to human life.

\section{Public Safety and the Concept of Acceptable Risk}

What, then, can be considered an acceptable level of risk? Literally no human action is safe in the sense that it is attended by no risk. Indeed, a meaningful definition of "safe" would have to be something like "not adversely affecting the probability of survival to a material extent" or "accompanied by even less risk than alternative available options." Crossing the street is not safe; stepping into the bath is not safe; living is not safe. Life itself increases the probability of death. For inhabitants of the Umited States, the risk of death in any year increases from a minimum at age 11 of 37 per 100,000 to 26,477 per 100,000 at age 92.117 From the age of 30 on, the probability of dying in each year doubles for every eight years of living. ${ }^{118}$ An event which uniformly and permanently doubles the death rate of a population effectively ages it eight years and deprives it of eight years of life per person. ${ }^{119}$ Froin the perspective of a 30-year-old, such an event

117. U.S. Dep'T of HEW, 1 Unrted States Life Tables 1959-61, No. 1, at 8-9 (Public Health Service Pub. No. 1252, 1964).

118. P. Timiras, Developmental Physiology and Aging 594-95 (1972).

119. Permanently increasing the death rate in a cohort (in demography, a group of persons of the same age), reduces the life expectancy of its members to the same life expectancy they would have if their death rate had reached the higher level in the ordinary course of aging. In other words, the time lost from median life expectancy due to an mcrease in death rate is equal to the time which would be required in order to increase the death rate to the higher value in the normal course of aging. This well known relationship is not self evident but can be proven as follows:

Since the $\log$ of the death rate of a cohort (from about age 25 on) is directly proportional to its age it follows that

$$
\log -\frac{\mathrm{dC} / \mathrm{dt}}{\mathrm{C}}=\mathrm{Kt}+\mathrm{k}
$$

where $C$ is the number of individuals surviving in the cohort, $t$ is time, $K$ and $k$ are constants, and $\log$ is to the base e. Taking the antilog of both sides of the equation

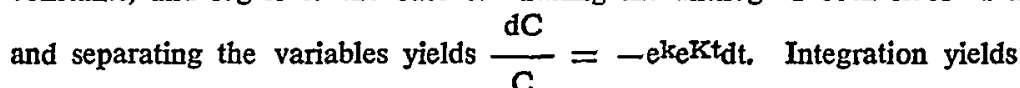

$$
\log C=\text { constant } \frac{-e^{e^{k}} e^{K t}}{K} .
$$

Dividing the initial size of the cohort at $t=0$ by the number surviving at time $t$ yields

$$
\log \frac{C_{0}}{C_{t}}=\frac{e^{k\left(e^{K t}-1\right)}}{K}
$$

When half the cohort has died, $\log C_{0} / C_{t}=\log 2=0.69$ and

$$
0.69=\frac{\mathrm{ek}^{\mathrm{k}}\left(\mathrm{e}_{\mathrm{Kt}}-1\right)}{\mathrm{K}} \text {. }
$$


would raise the expectation of death from 143 per 100,000 to 286 per 100,000 in the thirty-first year and shorten total life expectancy froin 73.2 to 65 years. ${ }^{120}$ From the perspective of the observer of the population, the event would cause the death, on the average, of 14330 year-olds in every 100,000 who would not otherwise have died.

On the other hand, if instead of doubling the risk of death, the event raises it by only 0.02 percent, the death rate would be 143.03 per 100,000 for 30 -year-olds. Every person 30 years of age or older would lose one day of life expectancy. This level of risk almost certainly hes within the realm of "safe." There are few undertakings we would be willing to forego merely to lengthen our lives one day. Admittedly, even this tiny increase in risks will take the life of 2930 -yearolds out of every 100 million who would not otherwise have died. But viewed another way, it means that of every 143,029 30-year-olds who die, 143,000 would die even if the added risk is avoided.

The value of $t$ in (4) is the time required for half the cohort to die and is therefore the median life expectancy $\left(\frac{t_{1}}{\frac{1}{2}}\right)$. Solving (4) for $t_{\frac{1}{2}}$ yields

$$
\frac{t_{1}}{2}=\frac{\log \left[1+\frac{K(0.69)}{e^{k}}\right]}{K} .
$$

From (1) it is apparent that $\mathrm{e}^{\mathrm{k}}$ is the initial death rate $\left(\mathrm{D}_{\mathrm{o}}\right)$. Since the doubling time for the death rate (D) is 8.3 years (see note 118 supra) from (1), $K$ is calculated to be 0.083 . For young adult ages, $\mathrm{D}<<\mathrm{K}$ (D is .001 at age 30 , see note 117 supra) and therefore

(6) $\quad \log \left[1+\frac{\mathrm{K}(0.69)}{\mathrm{D}}\right] \cong \log \frac{\mathrm{K}(0.69)}{\mathrm{D}}$.

If $D$ is raised from $D_{0}$ to $D_{0}^{\prime}$, and $D_{0}$ and $D_{0}^{\prime}$ are still $<<K$, it follows from (5) and (6) that the time lost from the median life expectancy is

$$
t_{\frac{1}{2}}-t_{\frac{1}{2}}^{\prime}=\frac{\log \frac{K}{D_{0}}(0.69)-\log \frac{K}{D_{0}^{\prime}}(0.69)}{K} .
$$

If $\frac{t_{1}}{2}-t_{\frac{1}{2}}^{\prime}$ is $\Delta t$, then

$$
\Delta t=\frac{\log D_{0}^{\prime}-\log D_{0}}{K}
$$

However, from $(1), \log D=K t+k$. If $D$ at time $t_{1}$ equals $D_{0}$, and increases due to aging to $D_{0}^{\prime}$ at $t_{2}$, it follows from (1) that

(9) $\log D_{0}^{\prime}-\log D_{0}=K\left(t_{2}-t_{1}\right)$

But from (8) $\log D_{0}^{\prime}-D_{0}=\Delta t K$ so that $\Delta t=t_{2}-t_{1}$.

120. See notes 117 and 119 supra. It should be noted that total life expectancy is used here to mean the age of the cohort when half is dead. In contrast, life expectancy $\left(t_{\frac{1}{2}}\right.$ in note 119 supra) is the time remaining until half of the cohort is dead.

Hence total life expectancy equals present age of a cohort plus its present life expectancy. 
It seems evident, then, that risk can only be evaluated in relation to its contribution to total existing risk. To say that a policy causes a risk of death per year to 30-year-olds of 29 per 100 million is much less informative than to say that it increases the 30-year-old's risk of death by 0.02 percent. The latter statement also seems preferable because the former tends to make us forget that 30-year-olds are not immortal, that 143,000 would die with or without our policy.

Those who support strict interpretation of the Delaney clause often seem to ignore the significance of extremely low risk levels. For example, opponents of DES have suggested that a risk level of 1 per 100 million should be adopted as the operational definition of "virtual safety,"121 even though this level of risk is only one-thirtieth of the minuscule hazard level just discussed.

\section{Scientific Appraisal of the Delaney Clause}

The foregoing lays the groundwork for appraismg the scientific merits of the policy of the Delaney clause. ${ }^{122}$ Initially, by selecting carcinogens for special treatunent, the clause draws a distinction among substances which is so circumstantial as to be almost fortuitous. For purposes of the clause, a carcinogen is simply a substance for which an investigator has designed an experiment that will allow the material to increase the probability of cancer. There is no guarantee that all substances are not in some circumstances carcinogens, perhaps even normal nutrients, since anything which enhances the rate of cell division may be expected to imcrease the time rate of cancer occurrence. ${ }^{123}$

The clause does not distinguish between potent carcinogens and weak ones, but it does draw a line between weak carcinogens and poisonous substances whose carcimogenicity simply has not been demonstrated. Such a policy can hardly be a sensitive instrument for promoting public welfare. Indeed, rigorous enforcement of the policy invites contrived experimentation designed to outlaw any food-processing practice that seizes the attention of the experimenter; all that is necessary is to find the conditions under which the practice increases the incidence of cancer in a test animal.

121. Regulation of Diethylstilbestrol, Hearings on H.R. 8708 Before a Subcomm. of the House Comm. on Gov't Operations, 92d Cong., 1st Sess., pt. 2, at 115-16 (1971).

122. Not considered here are potential problems of differences between the sensitivities of humans and experimental animals to carcinogens and the species-specificity of carcinogens.

123. See the discussion of "promotion" in Principles of Drug Action, supra note 85, at 673-77. Chemical carcinogens may be classified as initiators or promoters (some may have both functions). There is evidence that initiators act, in general, by producing cell mutations while promotors act by stimulating cell division. See Knudson, Mutation in Human Cancer, 17 AdVANCES IN CANCER RESEARCH 317, 339 (1973). 
The policy of prohibiting tolerance levels is inconsistent with basic knowledge about the relationship between the amount of a substance administered to an animal and the injury induced. Carcinogens, like other substances, produce harm in proportion to their concentration. Accordingly, for every carcinogen there exists a concentration which corresponds to whatever low level of risk one wishes to define as "safe." To adopt a posture that no additional risk is safe is to apply a policy that would terminate virtually every human enterprise if carried to logical extremes. When such a policy is applied to foods, it has the potential to cause greater risk than it prevents. By singling out one particular risk, the risk of cancer, the policy requires reducing that risk without regard to concomitant increases in other risks. In sliort, the policy precludes the rational weighing of cost against benefit in the contemplation of any particular substance as a food additive.

Moreover, the clause substitutes an inflexible legislative standard for administrative discretion in the management of a technical problem. That the problem is within the peculiar technical expertise of the FDAand beyond the experience of the legislature-suggests in itself that the policy would tend to deprive the public of the benefit of informed judgment. In this respect the clause is inconsistent with the other related sections of the FDCA, which invest the FDA with discretion as a means of effectuating congressional intent to ensure the wholesomeness of food.

In summary, the Delaney clause is so much out of step witli related provisions of the FDCA, as well as with accepted principles of science, that it provokes curiosity about how it came to be adopted. Fortunately, there is an extensive legislative record to shed light on this historical anomaly.

\section{III}

\section{Legislative Origins of the Delaney Clause}

The legislative origins of the Food Additives Amendment can be traced to the formation, in 1950, of the House Select Committee to Investigate the Use of Chemicals in Foods and Cosmetics, under the chairmanship of Congressman James J. Delaney of New York. ${ }^{124}$ The committee's report of June 30,1952, urged amendment of the FDCA to subject chemical additives to safety requirements. ${ }^{125}$ Bills for that purpose were introduced to the Eighty-third Congress, ${ }^{126}$ and the Subcommittee on Health and Science of the Committee on Interstate and

124. 1958 U.S. CODE CoNG. \& AD. News, 85th Cong., 2d Sess. 5302.

125. Id.

126. 1958 U.S. Code Cong. \& AD. News, 85th Cong., 2d Sess. 5303. 
Foreign Commerce held hearings during the next term on ten bills. ${ }^{127}$ Throughout the Eighty-fourth Congress, controversy over procedures for agency review of the safety of food additives and provision for judicial review of agency discretion blocked legislation on the subject. ${ }^{128}$

- During the Eighty-fifth Congress, the House subcommittee held hearings on nine related bills. ${ }^{129}$ Only one of these measures contained a special provision for carcinogens. The umique bill was H.R. 7798, sponsored by Congressman Delaney. ${ }^{130}$ The Delaney proposal had formidable competition from rival measures, including one drafted by HEW. ${ }^{131}$ The subcommittee took testimony on the bills from representatives of industry, labor, consumer organizations, HEW, and the FDA. ${ }^{132}$ Expert scientific opinion was obtained from a panel of scientists selected by the National Academy of Sciences (NAS) at the request of the subcommittee, ${ }^{133}$ and expert advice on administrative law was received from the chief judge of the Third Circuit, who appeared on behalf of the Judieial Conference of the United States. ${ }^{134}$

The subcommittee weighed the information and opinion collected in eleven days of testimony with the various legislative proposals before it. A synthesis was achieved in a new bill introduced by the subcominittee's chairman, Congressinan John Williams of Mississippi. The compromise bill, H.R. 13254, was reported unanimously by the subcommittee to the full committee, which in turn unanimously reported it with only minor changes to the House on July $1,1958 .{ }^{135}$

This bill, which lacked any carcinogen clause, was destined to become the Food Additives Amendment of 1958. That clause was subsequently inserted in the bill at the insistence of Congressinan Delaney, who stated that he had been "deeply disappointed" to find that H.R. 13254 did not contain a specific carcimogen prohibition. ${ }^{130}$ Making his displeasure known, Congressman Delaney entered into prolonged negotiations with the FDA and in the end prevailed upon the committee to adopt a carcinogen amendment to the bill. ${ }^{137}$ The amended bill

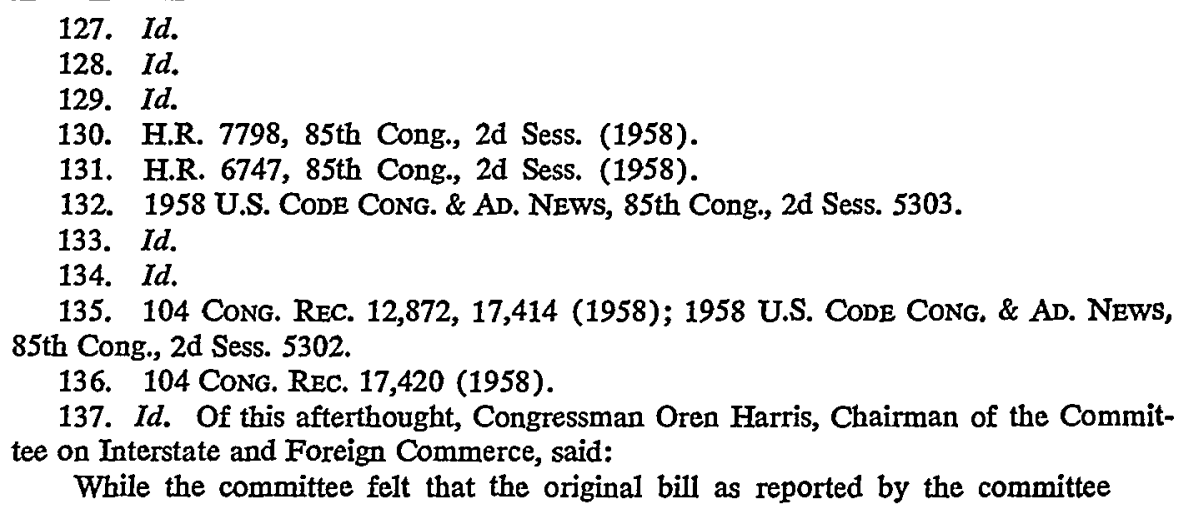

137. Id. Of this afterthought, Congressman Oren Harris, Chairman of the Committee on Interstate and Foreign Commerce, said:

While the committee felt that the original bill as reported by the committee 
finally passed the House on August 13, 1958. ${ }^{138}$ It was approved by the Senate essentially unchanged and signed into law by President Eisenhower shortly thereafter.

As the record clearly indicates, the responsible committees of both chambers of Congress intended that the measure promote increased protection of public health and facilitate use of innovative chemical food technology. ${ }^{139}$ Moreover, the committees unreservedly endorsed establishment of tolerance levels in food for previously prohibited noxious substances. ${ }^{140}$ Manifestly, the intent of Congress was that the new measure "fine tune" the FDCA to the requirements of modern food technology. The bill was designed to impose prudent restraints on the use of untested additives until their properties becaine known, while relaxing the prohibition against poisons when the FDA could certify a beneficial and safe use. On the whole, the Amendment

includes the matter covered by the Delaney amendment in the general language contained in the bill, there was no objection to the addition of the amendment. ...

Id. at 17,414 (1958). This last-minute addition represeuted a victory for Delaney, who had championed the no-tolerance policy for carcinogens since the preceding year when he had introduced H.R. 7798. This bill was one of nine (in reality, there were seven distinct bills, as two pairs were identical) which had been considered by the House subcommittee during the extensive hearings of 1957-58. 1598 Hearings, supra note 15, at 47 , 49. The Delaney bill had formidable competition, including H.R. 6747, an administration ineasure drafted by HEW, and in the end the subcommittee's bill contained no carcinogens phrase. As bas been seen, however, Congressinan Delaney refused to accept defeat so easily, and he continued to exert pressure in favor of a carcinogen clause.

138. 104 CONG. REC. 17,424 (1958).

139. The formal legislative history of the Food Additives Amendment of 1958 is drawn from the report of the Committee on Labor and Public Welfare, which reported the Amendment to the Senate for passage. 1958 U.S. CODE CONG. \& AD. NEwS, 85th Cong., 2d Sess. 5300-11. It recites that the purpose of the Amendment is twofold: first, to promote the public health by requiring the pre-testing of new and unproven food additives; second, to promote the use of innovative food technology by permitting the use of safe amounts of previously banned additives.

140. The pro-technology objectives of the law are made explicit in passages of the report which state that the previously existing law had proved detrimental to consumers, processors, and to the national economy because its provisions had proscribed the use of certain additives to preserve food or improve its flavor. The House Committee expressly approved the FDA's request to change pre-existing law to permit exploitation of advances made in technology by allowing the use of additives in amounts conforming to FDA-prescribed tolerances. Id. at 5301. Chairman Harris spoke in support of the bill on August 13, 1958, the day H.R. 13254 passed the House. He stated that the purpose of the legislation was twofold: to protect the health of consumers by requiring manufacturers of food additives to pretest substances before adding thein to food, and to advance food technology by permitting the use of food additives at safe levels. He noted that the then-existing law prohibited the use, even at safe levels, of poisonous additives unless their use was required in production or could not be avoided by good manufacturing practice. The existing law, he concluded, should be changed both to prohibit use of untested additives and to permit use of poisonous additives if their use at safe levels would advance food technology and increase and improve the food supplies. 104 CONG. REC. 17,413 (1958). 
seems a model of contemporary, rational, cost-benefits legislation. Against this background, the Delaney clause's exclusion of carcinogens, alone among all possible substances, calls for an explanation.

- It is instructive to compare the clause in the amendment with the phrase in Delaney's earlier bill, H.R. 7798. The earlier bill stated: "The Secretary slall not approve for use in food any clemical additive found to induce cancer in man, or, after test, found to induce cancer in animals." ${ }^{41}$ Comparing this language with the clause as it now exists in section $348,{ }^{142}$ it can be seen that the current clause is considerably less restrictive than the one originally proposed. Only those carcinogens are proscribed which are thought to be effective when taken orally.

But even more significant than the extent to which Delaney's clause was modified is the way it came to be revised. The language of the clause as it now exists is, in fact, the exact language offered by HEW in a letter to Chairman Harris dated August 8, 1958. 143 The letter, from HEW's Assistant Secretary Richardson, explaimed the position of HEW on the Delaney request. The Department, he wrote, was "im complete accord with the intent . . . that no substance should be sanctioned for uses $i$ food that might produce cancer in man."144 $\mathrm{He}$ urged, lowever, that H.R. 13254 without the Delaney amendment would accomplish this intent, because the bill provided that no hicense for an additive would issue unless "the proposed use of the additive will be safe."145 Any indication that the additive might be carcinogenic would, he stated, "restrain the Secretary from approving the proposed use ... unless . . . further testing show[ed] ... that the additive would not produce cancer and would thus be safe under the proposed conditions of use." ${ }^{148}$

The letter criticized the strict no-tolerance-for-carcimogens policy as possibly having "undesirable results . . . . Concentrated sugar solutions ... and even cold water have been reported to cause . . . cancer at the site of [repeated] imjection . . . . But scientists lave not suggested that these same substances cause cancer when swallowed ..."147 Richardson concluded:

The enactment of a law which would seem to bar such common materials from the diet ... would place the agency . . . in an untenable position. The agency would either have to try to enforce the

141. 1958 Hearings, supra note 15 , at 12 .

142. See text accompanying note 39 supra.

143. 104 CONG. ReC. 17,415 (1958).

144. Id.

145. Id. (emphasis added).

146. Id.

147. Id. 
law literally . . . evidently an impossible task-or it would have to read between the lines of the law an intent which would make the law workable, without a clear guide from Congress as to what was meant. ${ }^{148}$

The letter then offered the language of the current Delaney clause as a means of avoiding the difficulty described. Thus, in its effort to placate Congressman Delaney, HEW drafted the clause which ultimately caused the cyclamate debacle and which indirectly led to the DES scandal.

Considering its position in the summer of 1958, one can speculate that HEW was helpless to avoid these difficulties. It had already run the gauntlet of subcommittee hearings in which its own measure, H.R. 6747 , faced eight competing bills. The legislation was controversial and technically troublesome, especially the provisions for administrative and judicial review which had already stalled enactinent of a law in the Eighty-fourth Congress. There was an air of impatience about further delays, ${ }^{140}$ and HEW itself strongly favored adopting a law during that session. In this context, the Delaney clause inust have been seen as a comparatively minor issue..$^{150}$

When Congressman Delaney refused to take no for an answer, HEW was put in a difficult position. If it remained intransigent on this one provision of the legislative package, it would risk imcurring Delaney's opposition in and out of Congress. ${ }^{151}$ Because his name had been widely associated with the crusade to protect the public from untested additives, and since he had been instrumental in keeping the issue before Congress, Delaney's influence must have been substan-

148. Id.

149. Subcommittee Chairman Williams stated at the opening of the 1957 hearings:

I realize that the field of chemical additives is complex and that the legal problems involved in this legislation are important. However, it seems to me that a 10-year period is a sufficiently long mcubation period even for difficult legislation.

1958 Hearings, supra note 15 , at 50.

150. Before the Commerce Committee's subcommittee, Richardson was restricted to fighting for the administrative review procedure HEW wanted. Id. at 420-28. Four of the nime bills-H.R. 366, 8930, 8629, 10404-had provisions for judicial review of administrative discretion which severely threatened the FDA's capacity to move decisively against hazardous additives.

In his extensive testimony, id. at 446-496, FDA Commissioner Gcorge Larrick was able to give only the briefest attention to the carcinogen clause:

[H.R. 6747, HEW's bill1 would prohibit the addition of any chemical additive to the food supply until adequate evidence, . . . shows that it will not produce cancer in man under the conditions of use proposed.

But we see no inore reason to single out cancer . . . for specific inention ... than ... [any one of] a host of other disorders.

Id. at 453-54.

151. He obliquely threatened to oppose the bill if it had no carcmogen clause. 104 CONG. REC. 17,420 (1958). 
tial. ${ }^{152}$ If it stood up too stiffly to his demands, HEW faced the prospect of politically damaging accusations that it was soft on food adulterators. Perhaps worst of all, serious controversy might block passage of the entire bill. Time was running out, and HEW took only a month to come up with the compromise language. In its version, HEW seems simply to have opted for the lesser evil. The clause was stringent enough for Delaney to accept, but it at least avoided the obvious pitfalls of failing to discriminate between carcinogenesis resulting from local tissue irritation ${ }^{153}$ and carcinogenesis related to dietary administration of chemical substances.

It seems fair to conclude that the clause was essentially the personal hobbyhorse of James Delaney. He seems to have found no enthusiastic riders for it in the House or Senate committees or in HEW or the FDA. Indeed, the record suggests that in ratifying the Food Additives Amendment of 1958 Congress probably did not conteinplate a substantial difference in policy between regulation of carcmogens and other noxious substances. ${ }^{154}$ Nevertheless, with all its defects, the Delaney clause is today the law.

\section{IV}

Lessons of the Delaney Clause: ScIENCE, AdVocacy, AND the Proper Separation of Roles

The preceding discussion suggests that the Delaney clause is an ineffective instrument for promoting the public interest. Moreover, its

152. Chairman Harris, speaking for H.R. 13254 in the House on August 13, 1958, noted:

[T] he food additive legislation which the Committee on Interstate and Foreign Commerce has reported unanimously bears the imprint of James J. Delaney, our esteemed colleague from New York. Without Jim Delaney's efforts on behalf of this legislation there might well not be any food additive legislation and it is therefore fitting for the Committee on Interstate and Foreign Commerce to pay tribute to our colleague today.

104 CoNg. Rec. 17,413 (1958).

153. For a description of carcinogenesis by local irritation, see PrINCIPLes of Drua Action, supra note 74, at 673-77.

154. The Senate Committee on Labor and Public Welfare, favorably reporting H.R. 13254, had this to say of the Delaney clause:

We have no objection to that amendment whatsoever, but we would point out that in our opinion it is the intent ... of this bill, even without that amendment, to assure our people that nothing shall be added to the foods they eat which can reasonably be expected to produce any type of illness . . . but we want the record to show that in our opinion the bill is aimed at preventing the addition to the food our people eat of any substances . . . which reasonable people would expect to produce . . . any disease ... . we believe the bill reads and means the same with or without the inclusion of the clause referred to. This is also the view of the [FDA].

1958 U.S. CODE CONG. \& AD. News 5309-10.

Also noteworthy in this regard was the exchange between Chairman Harris and Congressman Miller of Nebraska on the House floor on August 13. Miller's objec- 
shortcomings were recognized at the outset by both the executive and legislative branches of government. ${ }^{155}$ To what, then, can we attribute the enactment and continued existence of this inappropriate statute?

Although the impetus for passage of the clause originated froin the energy and determination of James Delaney, it is unlikely that the clause would have been written and enacted without support from a significant sector of the scientific community. In fact, Congressman Delaney obtained inspiration for his statute from the opinions of eminent scientists engaged in cancer research. ${ }^{156}$

A scientific body called the International Union Against Cancer (IUC) recommended unanimously that the use of carcinogens in food be prohibited in August, 1956, a year before Congressman Delaney introduced his bill.157 In 1958, the policy of the Delaney clause was supported in testimony before the Commerce Committee by three scientists involved in cancer research. ${ }^{158}$ They were Dr. William Smith, an American officer of the IUC, ${ }^{159}$ Dr. W. C. Hueper of HEW's National Cancer Institute (NCI), ${ }^{180}$ and Dr. Francis E. Ray ${ }^{161}$ of the Cancer Research Laboratory of the University of Florida. The Comunerce Committee also heard testimony from an expert panel nominated by the $\mathrm{Na}$ tional Academy of Science (NAS). ${ }^{162}$

The record indicates that in general the discussions lacked scientific rigor. ${ }^{103}$ No searching appraisal was made of the concept of chemical carcinogenesis, and the significance of carcinogen potency and concentration remained largely unexplored. Dr. Ray's testimony, for example, revealed that he doubted cancer could be induced by ordinary substances such as salt and sugar. ${ }^{104}$ He apparently believed that carcinogens are an exceptional and restricted class of substances, a belief that now appears to be clearly wrong. ${ }^{165}$ This fundamental error,

tions-that the clause was unadministrable because of the breadth of the carcinogen category and that the FDA must surely oppose it on the same ground-were silenced by Harris, who stated that the FDA had no objections aud that if any problem arose the FDA could simply seek congressional reappraisal. 104 CoNG. REC. 17421 (1958).

155. But see Turner, The Delaney Anticancer Clause: A Model Environmental Protection Law, 24 VAND. L. REv. 889 (1971).

156. 1958 Hearings, supra note 15 , at 498.

157. Debate, supra note 8 , at 589 .

158. 1958 Hearings, supra note 15 , at 498 .

159. Id. at 169 et seq.

160. Id. at 369 et seq.

161. Id. at 199 et seq.

162. Id. at 305-86.

163. Id.

164. Id. at 202 .

165. Subcutaneous implantation of clean glass causes sarcomas in rats. That the effect is not attributable to chemical carcinogens contaminating the glass was demonstrated when implantation of powdered glass failed to produce cancer. PRncIPLES of DRUg Acrion, supra note 85 , at $675-76$. 
among others, went uncorrected at least in part because it was not subjected to a searching and critical appraisal based on the broadest knowledge available. The shorthand term for such a failure is "bad science."

I The scientific method, however, contains built-in correctives to such failures. Ordinarily one could expect that the energetic debate which characterizes scientific discussions would result in a reversal of the original recommendation. But this has not taken place. What we have witnessed instead is a bitter polarization anong scientists. The Food Protection Committee of the NAS becaine locked in conflict with promment spokesmen from NCI. ${ }^{168}$ This clash was so tainted by bigotry that one nationally known scientist made a well publicized demand that NAS be investigated for conflict of interest. ${ }^{107}$ Even Science magazine wrote that "[a]ny claim by the NAS food protection committee to be an independent, unbiased, and representative body of experts must be weighed against [its support] by grants from the food, chemical and packaging industries." 168 It also noted that five of nine scientists who prepared a 1969 report critical of the clause were employed by food or chemical companies. Science termed the dispute between NAS and NCI "an interesting instance of the scientific method, supposedly pure and impartial, failing to triumph over the particular perspectives of its practitioners."

A recent convocation sponsored by the New York Academy of Sciences gives further evidence of the extent to which scientific objectivity over the Delaney clause has deteriorated. The meeting, billed as "The Scientific Basis for the Delaney Amendment," was described by Science as little more than a last-minute attempt to head off any inove to soften the clause. ${ }^{170}$ The magazine reported that the "often passionate feelings" people have about the anti-cancer clause were on prominent display throughout the meeting. ${ }^{171}$

Such tactics, everyday occurrences in the political arena, are remarkable when they take place in the scientific cominunity. In scientific discourse it is customary for each scientist to accord the greatest respect to the arguments made in support of the conflicting conclusions of others. ${ }^{172}$ Each scientist strives to find the exact point at which

166. Debate, supra note 8, at 589.

167. E.g., San Francisco Examiner, Sept. 20, 1972, at 2, col. 1, reporting on the testimony of Dr. S. Epstein before the Senate Select Committee on Nutrition and Health needs.

168. Wade, DES: A Case Study of Regulatory Abdication, 177 ScIEnce 335, 337 (1972).

169. Debate, supra note 8, at 589.

170. Uncertain Threat, supra note 8, at 666.

171. Id.

172. J. KEMENY, supra note 76 , at $87-88$, describes a typical example in which assiduous attention to a single conflicting finding led to a major scientific discovery. 
an opponent's reasoning diverges from his own, with the goal of findind a common ground of agreement and assimilating apparently disparate conclusions in order to arrive at a synthesis which is nore nearly correct than the opinion of either individual. ${ }^{173}$

Whenever a scientific debate becomes unreasonably strident, and its participants unusually intransigent, one cannot help but suspect that technical matters are no longer the real issue. In such circumstances it is not unusual to find that opponents completely understand and accept the contents of each other's arguments. They carry on the debate because they favor opposing policies, not because they disagree about scientific matters. They perceive a policy decision as an implicit consequence of their technical conclusions, and having a personal preference for a particular policy they tend to defend whatever technical conclusion is unost conducive to their favored policy. In sliort, scientific objectivity is abandoned in favor of scientific advocacy.

The tone of the Delaney clause debate suggests that at least some scientist participants have long since becoine advocates. To the extent that this is true, they cannot be relied on to give the fair and objective testimony that society expects from scientists. Having historically relied upon science to provide factual and disinterested information, society may be confused by inisrepresentations by scientist-advocates.

What can be done to counter the harmful effects of such practices? For one thing, when scientific debate becomes tinged with emotional, political, or pecuniary overtones-that is, when it begins to take on the nature of an adversary process - the ordinary safeguards of adversary proceedings, such as cross-examination and appointment of counsel, should be instituted. Such measures can help counteract the personal or organizational biases of individual witnesses and ensure that all points of view, including those of the consuming public, are represented. 1

A second step would be siniply to realize that as scientists take on more and more the role of advocates, those who advocate the public interest, such as legislators and attorneys, nust in turn become scientists. If scientific testimony and advice are to be frankly recognized for what they commonly are-advocacy of a particular policy interest-individuals charged with conducting these proceedings must come to possess a modicum of scientific expertise. It is tempting to think that the debate over the Delaney clause might not have proven so fruitless had attorneys and legislators involved in its enactunent taken the trouble to inform themselves of the applicable science.

173. See id. at 88-89; N. CAMPBELL, supra note 74, at 64-69. 


\section{CoNCLUSION}

- It is probably now too late to remedy the deficiencies of the Delaney clause. The weight of misinformation that has circulated in support of the clause and the emotionalism it has engendered are likely to prove irresistible. ${ }^{174}$ Even were Congress to obtain scrupulously honest and detached scientific counsel from unimpeachably disinterested sources, the force of public opinion would stand in the way of change.

Technical naïveté and scientific advocacy need not, however, be forever tolerated in the formulation of national policy. In years to come, the legislative and executive branches of the federal government will be called upon increasingly to regulate tcchnology in the public interest. The need to allocate scarce resources, protect the environment from further dcterioration, and protect the consumer from unsafe products will require a multitude of policy decisions, each of which will have far-reaching implications. Lawyers prepared to reason with science as well as with law can lielp make policies better suited to serve the public interest and less likely to evidence the fatal weaknesses of the Delaney clause.

174. Kleinfield, The Delaney Proviso-Its History and Prospects, 28 FoOd Druo CosM. L.J. 562-63 (1973). 